\title{
THE IMPROVEMENT OF COMMUNITY KNOWLEDGE, ATTITUDES AND PRACTICES AFTER COVID-19 SOCIALIZATION
}

\author{
Siti Khaerunnisa' ${ }^{1}$ Irmi Syafa'ah ${ }^{2}$, Citrawati Dyah Kencono Wungu ${ }^{1}$, Gwenny Ichsan Prabowo ${ }^{1}$, Retno \\ Handajani $^{1}$, Indri Safitri ${ }^{1}$, Harianto Notopuro ${ }^{1}$, Ema Qurnianingsih ${ }^{1}$, Lina Lukitasari ${ }^{1}$, Ira Humairah ${ }^{1}$, \\ Arief Bakhtiar ${ }^{2}$, Suwandito Suwandito ${ }^{1}$, Susi Wahyuning Asih ${ }^{3}$, Zuhrotul Eka Yulis Anggraeni ${ }^{4}$, Ginanjar \\ Sasmito Adi ${ }^{5}$, Ely Rahmatika Nugrahani ${ }^{6}$, Ayesie Natasha Zulka ${ }^{6}$, Soetjipto Soetjipto ${ }^{1}$
}

${ }^{1}$ Department of Physiology and Medical Biochemistry, Faculty of Medicine, Universitas Airlangga, ${ }^{2}$ Department of Pulmonology and Respiratory Medicine, Dr Soetomo General Academic Hospital/Faculty of Medicine, Universitas Airlangga, ${ }^{3}$ Department of Community Health Nursing, Faculty of Health Science, University of Muhammadiyah Jember, ${ }^{4}$ Department of Paediatric Nursing, Faculty of Health Science, University of Muhammadiyah Jember, ${ }^{5}$ Department of Medical and Surgical Nursing, Faculty of Health Science, University of Muhammadiyah Jember, ${ }^{6}$ Department of Mental Health Nursing, Faculty of Health Science, University of Muhammadiyah Jember

\section{ABSTRACT}

This study was to determine community knowledge, attitudes, and practices after COVID-19 socialization in Rambipuji and Suci Village, Jember District, East Java, Indonesia. This study used the analytic observational design study. As many as 40 people were given socialization about COVID-19 by gathering and online. The questionnaires were completed in two parts including before-socialization and after-socialization. The questionnaires data were analysed descriptively by calculating frequency, percentages and inferential statistics by t-test, spearman correlation and chi square test. The data analysis used IBM SPSS version 23 software. The mean and standard deviation of percentage of knowledge pre-test, knowledge post-test, high attitude, moderate attitude, low attitude, very high practice, high practice, sufficient practice, and low practice were 58.33 $\pm 30.97,77.70 \pm 22.52,62.5 \pm 21.7,31 \pm 22.2,6.5 \pm 17.1,65 \pm 13.8,32.3 \pm 13.8,1.25 \pm 2.4,1.25 \pm 1.8$, respectively. Knowledge pretest and post-test had a correlation of $0.819(p=0.001)$ and $t$-test with $p=0.003$. Attitudes and practices had a correlation with $p=0.001$. Socialization of COVID-19 was useful to improve the community knowledge, attitudes, and practices in Rambipuji and Suci Village, Jember District, East Java, Indonesia which could prevent the transmission and inhibit the spread of the COVID-19 pandemic in Indonesia. Furthermore, continuous encouragement of COVID-19 socialization in wide areas was recommended.

Keywords: community; knowledge; attitude; practice; Jember

\section{ABSTRAK}

Penelitian ini bertujuan untuk mengetahui pengetahuan, sikap, dan perilaku masyarakat setelah sosialisasi COVID-19 di Desa Rambipuji dan Suci, Kabupaten Jember, Jawa Timur, Indonesia. Penelitian ini menggunakan desain penelitian observasional analitik. Sebanyak 40 orang diberikan sosialisasi tentang COVID-19 secara tatap muka (luring) dan daring. Kuesioner diisi dalam dua sesi yaitu sebelum sosialisasi dan setelah sosialisasi. Data kuesioner dianalisis secara deskriptif dengan menghitung frekuensi, persentase dan statistik inferensial dengan uji-t, korelasi spearman dan uji chi square. Analisis data menggunakan perangkat lunak IBM SPSS versi 23. Rerata dan standar deviasi persentase pengetahuan sebelum test, pengetahuan setelah test, sikap tinggi, sikap sedang, sikap rendah, perilaku sangat tinggi, perilaku tinggi, perilaku cukup, dan perilaku rendah secara berturut-turut adalah 58,33 $\pm 30,97,77,70 \pm 22,52,62,5 \pm 21.7,31 \pm 22.2,6.5 \pm 17.1,65 \pm 13.8,32.3 \pm$ $13.8,1.25 \pm 2.4,1.25 \pm 1.8$. Pengetahuan sebelum test dan setelah test memiliki korelasi $0,819(p=0,001)$ dan $t$-test dengan $p$ $=0,003$. Sikap dan perilaku memiliki korelasi dengan $p=0,001$. Sosialisasi COVID-19 bermanfaat untuk meningkatkan pengetahuan, sikap, dan masyarakat masyarakat di Desa Rambipuji dan Suci, Kabupaten Jember, Jawa Timur, Indonesia yang dapat mencegah penularan dan menghambat penyebaran pandemi COVID-19 di Indonesia. Selain itu, sosialisasi COVID-19 terus didorong di berbagai wilayah.

Kata kunci: masyarakat; pengetahuan; sikap; perilaku; Jember

Correspondence: Siti Khaerunnisa, Department of Physiology and Medical Biochemistry, Faculty of Medicine, Universitas Airlangga, Surabaya, Indonesia. Email: st.khaerunnisa@fk.unair.ac.id

pISSN:2355-8393 • eISSN: 2599-056x • doi: 10.20473/fmi.v57i2.26262

- Fol Med Indones. 2021;57:95-103 • Received 07 Apr 2021 • Accepted 17 May 2021

- Open access under CC-BY-NC-SA license • Available at https://e-journal.unair.ac.id/FMI/ 


\section{INTRODUCTION}

Coronavirus disease 2019 (COVID-19) is a form of pneumonia caused by severe acute respiratory syndrome coronavirus 2 (SARS-CoV-2). The virus was first known to emerge from Wuhan, China in December 2019 (Wang et al 2020). It is a highly contagious disease that causes global pandemic, as stated by World Health Organization (2020). The symptoms of COVID19 are non-specific, and the disease presentation can range from asymptomatic to severe pneumonia and eventually, death (Aylward et al 2020). Reports from the centre for disease control and prevention (CDC) show that the disease's mean incubation period is 3-7 days and a maximum of 2 weeks. Although this disease's common manifestation is respiratory or lung symptoms, COVID-19 can also cause extrapulmonary manifestations and even systemic infections (Cascella et al 2020). There has been no specific therapy and there is still a lack of research on the treatment of COVID-19. However, the implementation that has been done is preventive and supportive therapy to prevent further complications and organ damage. (Rodríguez-Morales et al 2020).

Currently, the vaccine for COVID-19 is in the process of being developed. Although the process shows relatively rapid progress, the complexity of making the vaccine and the series of clinical trials required will need more time for the vaccine to be distributed widely to the community (Heaton 2020). Until then, early detection, case isolation, education for a clean and healthy lifestyle, and personal protection devices have been intensified to protect the population from infection (Wei-jie et al 2020). Physical distancing and the use of protective equipment such as face masks, respirators, and eye protection are known to reduce the risk of exposure to COVID-19 infection in the community if appropriately used (Chu et al 2020).

As of 16 September, the Government of Indonesia announced 228,993 confirmed cases of COVID-19, 9,100 deaths and 164,101 recovered cases from 493 districts across all 34 provinces. DKI Jakarta is the province with the most prevalent cases, followed by East Java (WHO 2020). Given the rapid rate transmission rate, low awareness of prevention, the lack of knowledge and the large amount of hoax information related to COVID-19 circulating in the community, especially in Indonesia, suppressing this virus become challenging. Thus, it is necessary to empower the community to be involved in preventing the transmission of COVID-19. One of them is through socialization to increase knowledge, attitudes, and practice towards COVID-19.
The results of our pilot survey analysis showed that the villages of Rambipuji and Suci, Jember Regency, East Java, were villages that had different characteristics. Both villages are located in East Java, the second most prevalent province with COVID-19 cases. Rambipuji village is a village located in an urban area and is on the provincial route. On average, the people of Rambipuji village have jobs as traders, labourers, and employees, which causes high mobility of villagers. Many villagers also leave the area to other cities for job-seeking, mostly cities with high COVID-19 cases, such as Surabaya, Sidoarjo, and Malang.

The number of community association in Rambipuji village reaches 20 with a high number of older adults as a high-risk group for COVID-19 transmission. Different from Rambipuji, Suji village is located in the countryside. Most of the population works as farmers, traders, and agricultural/construction labourers. This area consists of 16 community association with a high number of older adults. The mobility of residents outside the area is dominated by construction workers who work in affected cities such as Surabaya and Bali. In this program, we aimed to give a socialization program in Rambipuji and Suci villages to increase knowledge, attitudes, and practices; thus, we could reduce the incidence of COVID-19 infection in Indonesia, especially in high-risk areas.

\section{MATERIALS AND METHODS}

\section{Socialization and Study Setting}

This analytic observational study was performed in September 2020 located in Rambipuji and Suci Village, Jember District, East Java, Indonesia. As many as 40 people were given socialization consisting of three topics, namely (1) understanding and preventing of COVID-19, (2) myths and facts about COVID-19, and (3) the role of independent isolation communities. The questionnaires were completed in two parts including before-socialization (pre-test) and after-socialization (post-test) which included query of knowledge, attitude, and behaviour). Moreover, for the protection of participant and committee during data gathering, we applied the standard precaution, and were provided some tools, such as water and hand soap, nonsurgical 3 ply mask, face shield, antiseptic liquid, and thermo gun.

This socialization under community service programme had been carried out in two locations, namely Rambipuji and Suci village, Jember, East Java. Due to its socialization held during pandemic COVID-19, we had done the whole activities in two methods within a moment. In Rambipuji village, this socialization had 
been done offline (directly) with twenty participants in their meeting hall by obeying health protocol. The committee team for Rambipuji village came from the Faculty of Health Science, University of Muhammadiyah Jember. Meanwhile, this socialization has also been done online (indirectly) in Suci village with twenty participants by having a zoom meeting application. All the committee teams had affiliated with the Faculty of Medicine, Airlangga University. They had done their session online from their own home.

\section{Data Collection}

There were pre-test and post-test to measure participants' knowledge level about COVID-19. At the end of socialization, they had to complete the questionnaire to measure attitudes and practice level. The fulfilment of pre-test, post-test, and questionnaire had been done online and offline, while monitored by all the committee team. Quality assurance was accomplished by supervision on the data collection process, data extraction, data entry to the software, and data analysis.

\section{Data Analysis}

The data were entered into IBM SPSS version 23 software. The participant' demographics, COVID-19related knowledge, attitude, and practice were analysed using frequencies and percentages. Knowledge (pre-test and post-test) variable analysis was done using independent samples t-test. The correlation between knowledge, attitude and practices was evaluated by the Spearman correlation coefficient test. Chi-square test was applied to find difference in groups (good vs poor) by demographic characteristics. In the present study, $p$ value less than 0.05 was considered as significant level.

\section{RESULTS}

\section{Participants' Sociodemographic Characteristics}

This study included 40 participants from Rambipuji and Suci village. About half of the participants were residents of the Rambipuji and Suci Village of Jember Dictrict, Indonesia. Most of the participants were female $(67.5 \%)$. Most of the participants had categorized as productive age $(37.5 \%)$. They mostly had an education level as senior high school (65\%). 22,5\% among them were entrepreneurs. $97,5 \%$ of the participants were Javanese. The marital status of them was $47,5 \%$ married and $47,5 \%$ single (Table 1 ).
Table 1. Socio-demographic characteristics $(n=40)$

\begin{tabular}{ll}
\hline Characteristic & $n(\%)$ \\
\hline Village & $20(50)$ \\
Rambipuji & $20(50)$ \\
Suci & \\
\hline Gender & $27(67.5)$ \\
\hline Female & $13(32.5)$ \\
Male & \\
\hline Age (year) & $0(0)$ \\
\hline$<17$ & $15(37.5)$ \\
$17-25$ & $10(25)$ \\
$25-30$ & $2(5)$ \\
$30-35$ & $13(32.5)$ \\
$>35$ & \\
\hline Education & $1(2.5)$ \\
\hline Elementary School & $4(10)$ \\
Junior High School & $26(65)$ \\
Senior High School & $0(0)$ \\
Diploma & $9(22.5)$ \\
Bachelor, Master and Doctoral Degree & \\
\hline Occupation & $4(10)$ \\
\hline Civil servant & $8(20)$ \\
Housewife & $9(22.5)$ \\
Entepreneur & $0(0)$ \\
Farmer/Fisher & $3(7.5)$ \\
Private Employee & $6(15)$ \\
Unemployee & $10(25)$ \\
Others & $19(47.5)$ \\
\hline Marrital Status & $19(47.5)$ \\
\hline Married & $2(5)$ \\
Single & $39(97.5)$ \\
Divorced/Widowed/Widower & $1(2.5)$ \\
\hline Tribe & \\
\hline Javanese & \\
Maduranese & \\
\hline & \\
\hline
\end{tabular}

\section{Participants' Knowledge}

The mean percentage of knowledge for the pre-test was $58.33 \pm 30.97$, while the mean percentage of knowledge for the post-test was $77.70 \pm 22.52$. The most frequent items that showed the improvement of knowledge after socialization was about "Can sunlight kill corona virus directly?" (pre-test 37.5\%, post-test 90\%); "Does positive on rapid test mean you get infected corona certainly?" (pre-test $47.5 \%$, post-test 90\%); and "There are some actions that can be done by neighbours who know others doing self-isolation, except" (pre-test 45\%, post-test $72.5 \%$ ) (Table 2). 
Table 2. Knowledge before (pre) and after (post) socialization of COVID-19 ( $n=40)$

\begin{tabular}{|c|c|c|c|}
\hline \multirow{2}{*}{ No } & \multirow{2}{*}{ Item } & \multicolumn{2}{|c|}{ Completely Correct } \\
\hline & & Pre-test & Post-test \\
\hline 1 & What is the causes of COVID-19? & $97.5 \%$ & $100 \%$ \\
\hline 2 & $\begin{array}{l}\text { How is the diagnosis of COVID- } 19 \text { primarily } \\
\text { accomplished? }\end{array}$ & $70 \%$ & $95 \%$ \\
\hline 3 & $\begin{array}{l}\text { How many days are the self-isolation of confirmed } \\
\text { people who do not have any symptoms? }\end{array}$ & $12.5 \%$ & $45 \%$ \\
\hline 4 & $\begin{array}{l}\text { What are the right prevention steps of COVID-19 } \\
\text { transmission? }\end{array}$ & $97.5 \%$ & $97.5 \%$ \\
\hline 5 & $\begin{array}{l}\text { There are some roles of the head of neighbourhood if } \\
\text { his people have self-isolation, except...... }\end{array}$ & $30 \%$ & $37.5 \%$ \\
\hline 6 & How long is self-isolation? & $97.5 \%$ & $100 \%$ \\
\hline 7 & $\begin{array}{l}\text { There are some actions that can be done by } \\
\text { neighbours who know others doing self-isolation, } \\
\text { except.... }\end{array}$ & $45 \%$ & $72.5 \%$ \\
\hline 8 & Can sunlight kill corona virus directly? & $37.5 \%$ & $90 \%$ \\
\hline 9 & $\begin{array}{l}\text { Does positive on rapid test mean you get infected } \\
\text { corona certainly? }\end{array}$ & $47.5 \%$ & $90 \%$ \\
\hline 10 & Can asymptomatic patients deliver any viruses? & $85 \%$ & $85 \%$ \\
\hline 11 & Can be corona virus killed by hand soap? & $60 \%$ & $70 \%$ \\
\hline \multirow[t]{2}{*}{12} & Can the vaccine protect ourselves? & $20 \%$ & $50 \%$ \\
\hline & Mean $\pm \mathrm{SD}$ & $\begin{array}{l}58.3 \pm \\
30.9\end{array}$ & $\begin{array}{l}77.7 \pm \\
22.5\end{array}$ \\
\hline
\end{tabular}

The knowledge variable's inferential result (pre-test and post-test) showed a strong correlation of 0.819 $(\mathrm{p}=0.001)$ between those variables and a significant knowledge improvement (T-test with $\mathrm{p}=0.003$ ) after receiving COVID-19 socialization (Figure 1 and Table 3).

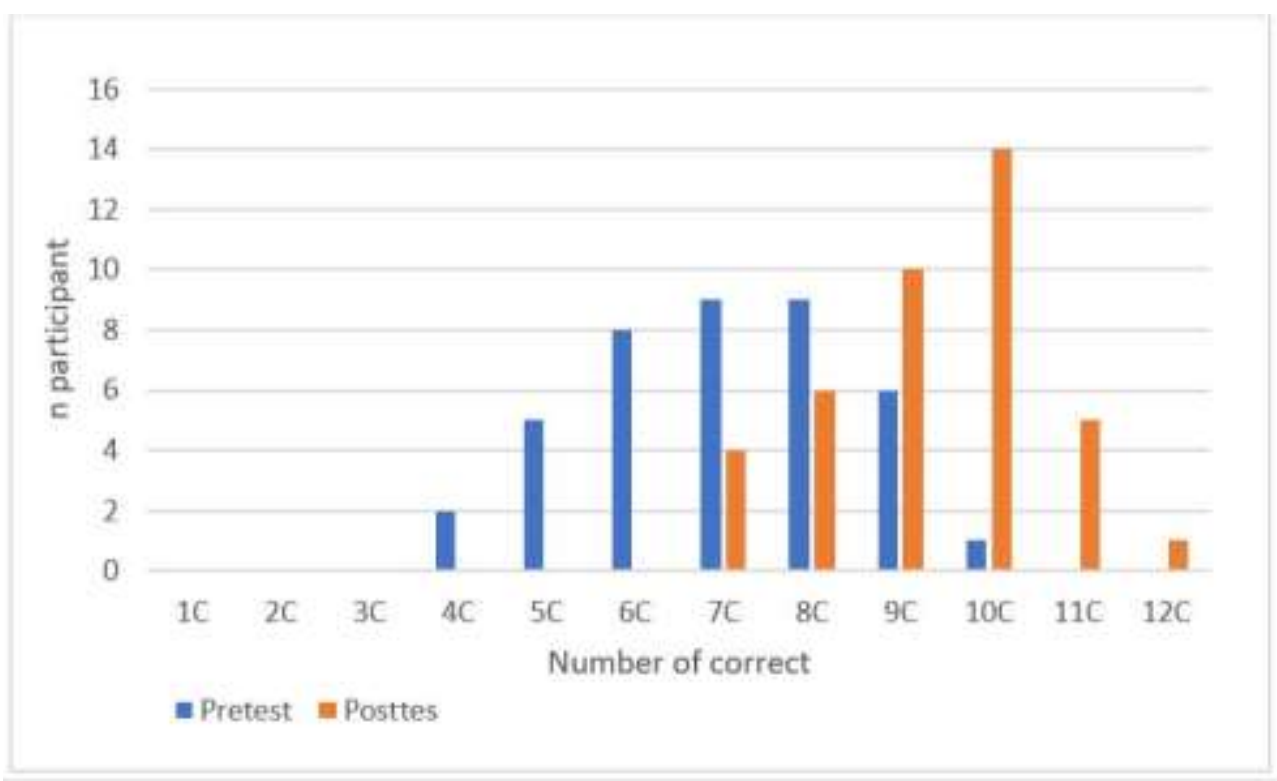

Figure 1. Bar diagram of the number of correct pre-test and post-test 
Table 3. Statistical analysis of knowledge before (pre) and after (post) socialization of COVID-19 by T-test

\begin{tabular}{|c|c|c|c|c|}
\hline \multirow[b]{2}{*}{ No } & \multirow[b]{2}{*}{ Knowledge } & \multirow{2}{*}{ Mean \pm SD } & \multicolumn{2}{|c|}{ T-test } \\
\hline & & & $\mathrm{dF}$ & $p$ \\
\hline 1 & Pre test & $58.33 \pm 30.97$ & 11 & $0.003^{*}$ \\
\hline 2 & Post test & $77.70 \pm 22.52$ & & \\
\hline
\end{tabular}

\section{Participants' Attitudes}

The mean of percentage of high participants' attitudes was $62.5 \pm 21.7$. It showed that most of the participants have good attitudes towards COVID-19 in their area. The most frequent answer that indicated good attitude could be seen on several items, namely "Do you wear your mask while you be in public area and private house?" (95\%); "Do you always wash your hands after touching down home?" (82,5\%); "Do you get your hand sanitizer while you out of home?" (67,5\%); "Do you eat any health and nutrient rich foods in daily?" $(62,5 \%)$; "Do you do exercise regularly?" (77,5\%); and "Have you ever given an advice to others, including your family, about the important of wearing mask and implementing health protocol both in public and private area?" (72,5\%) (Table 4).

Table 4. Attitudes after socialization of COVID-19 $(n=40)$

\begin{tabular}{|c|c|c|c|c|c|}
\hline No. & Item & Very High & High & Moderate & Low \\
\hline 1 & I wash my hands with running water & $87.5 \%$ & $12.5 \%$ & $0 \%$ & $0 \%$ \\
\hline 2 & I wear mask properly & $67.5 \%$ & $25.5 \%$ & $2.5 \%$ & $2.5 \%$ \\
\hline 3 & $\begin{array}{l}\text { I keep physical distance with others at least } 1-2 \\
\text { metres }\end{array}$ & $40 \%$ & $57.5 \%$ & $2.5 \%$ & $0 \%$ \\
\hline 4 & I choose to stay at home whenever I feel unwell & $67.5 \%$ & $30 \%$ & $0 \%$ & $2.5 \%$ \\
\hline 5 & I support others to have hand wash place & $70 \%$ & $30 \%$ & $0 \%$ & $0 \%$ \\
\hline 6 & $\begin{array}{l}\text { I always clean my home to protect my family } \\
\text { from corona virus }\end{array}$ & $55 \%$ & $45 \%$ & $0 \%$ & $0 \%$ \\
\hline 7 & Getting infected covid is not a disgrace to hide & $75 \%$ & $20 \%$ & $0 \%$ & $5 \%$ \\
\hline 8 & $\begin{array}{l}\text { I will give advices to whoever not obeying the } \\
\text { health protocol }\end{array}$ & $55 \%$ & $45 \%$ & $0 \%$ & $0 \%$ \\
\hline 9 & $\begin{array}{l}\text { I fully support neighbours who willing to self- } \\
\text { isolation }\end{array}$ & $77.5 \%$ & $22.5 \%$ & $0 \%$ & $0 \%$ \\
\hline \multirow[t]{2}{*}{10} & $\begin{array}{l}\text { I will not refuse the Covid corps to be buried in } \\
\text { my village area }\end{array}$ & $55 \%$ & $35 \%$ & $7.5 \%$ & $2.5 \%$ \\
\hline & Mean \pm SD & $65 \pm 13.8$ & $32.3 \pm 13.8$ & $1.25 \pm 2.4$ & $1.25 \pm 1$. \\
\hline
\end{tabular}

\section{Participants' Practices}

The mean of percentage of very high and high participants' practices were $65 \pm 13.8$ and $32.3 \pm 13$. It showed that the most of participants have good practices toward COVID-19 in their area. The most frequent answer that indicated good practices could be seen on several items, included "I wash my hands with running water" (very high $87,5 \%$ and high $12,5 \%$ ); "I support others to have hand wash place" (very high $70 \%$ and high $30 \%$ ); "I always clean my home to protect my family from corona virus" (very high 55\% and high 45\%); "I will give advices to whoever not obeying the health protocol" (very high 55\% and high $45 \%$ ); and "I fully support neighbours who willing to selfisolation" (very high $77,5 \%$ and high $22,5 \%$ ). 
Table 5. Practices after socialization of COVID-19 $(n=40)$

\begin{tabular}{|c|c|c|c|c|c|}
\hline No. & Item & Very High & High & Moderate & Low \\
\hline 1 & I wash my hands with running water & $87.5 \%$ & $12.5 \%$ & $0 \%$ & $0 \%$ \\
\hline 2 & I wear mask properly & $67.5 \%$ & $25.5 \%$ & $2.5 \%$ & $2.5 \%$ \\
\hline 3 & $\begin{array}{l}\text { I keep physical distance with others at } \\
\text { least } 1-2 \text { metres }\end{array}$ & $40 \%$ & $57.5 \%$ & $2.5 \%$ & $0 \%$ \\
\hline 4 & $\begin{array}{l}\text { I choose to stay at home whenever I } \\
\text { feel unwell }\end{array}$ & $67.5 \%$ & $30 \%$ & $0 \%$ & $2.5 \%$ \\
\hline 5 & $\begin{array}{l}\text { I support others to have hand wash } \\
\text { place }\end{array}$ & $70 \%$ & $30 \%$ & $0 \%$ & $0 \%$ \\
\hline 6 & $\begin{array}{l}\text { I always clean my home to protect my } \\
\text { family from corona virus }\end{array}$ & $55 \%$ & $45 \%$ & $0 \%$ & $0 \%$ \\
\hline 7 & $\begin{array}{l}\text { Getting infected covid is not a disgrace } \\
\text { to hide }\end{array}$ & $75 \%$ & $20 \%$ & $0 \%$ & $5 \%$ \\
\hline 8 & $\begin{array}{l}\text { I will give advices to whoever not } \\
\text { obeying the health protocol }\end{array}$ & $55 \%$ & $45 \%$ & $0 \%$ & $0 \%$ \\
\hline 9 & $\begin{array}{l}\text { I fully support neighbours who willing } \\
\text { to self-isolation }\end{array}$ & $77.5 \%$ & $22.5 \%$ & $0 \%$ & $0 \%$ \\
\hline 10 & $\begin{array}{l}\text { I will not refuse the Covid corps to be } \\
\text { buried in my village area }\end{array}$ & $55 \%$ & $35 \%$ & $7.5 \%$ & $2.5 \%$ \\
\hline & Mean \pm SD & $65 \pm 13.8$ & $32.3 \pm 13.8$ & $1.25 \pm 2.4$ & $1.25 \pm 1.8$ \\
\hline
\end{tabular}

The attitudes and practices variable's inferential result showed a robust correlation $(\mathrm{p}=0.001)$ between those variables after receiving COVID-19 socialization (Figure 2 and Table 6).

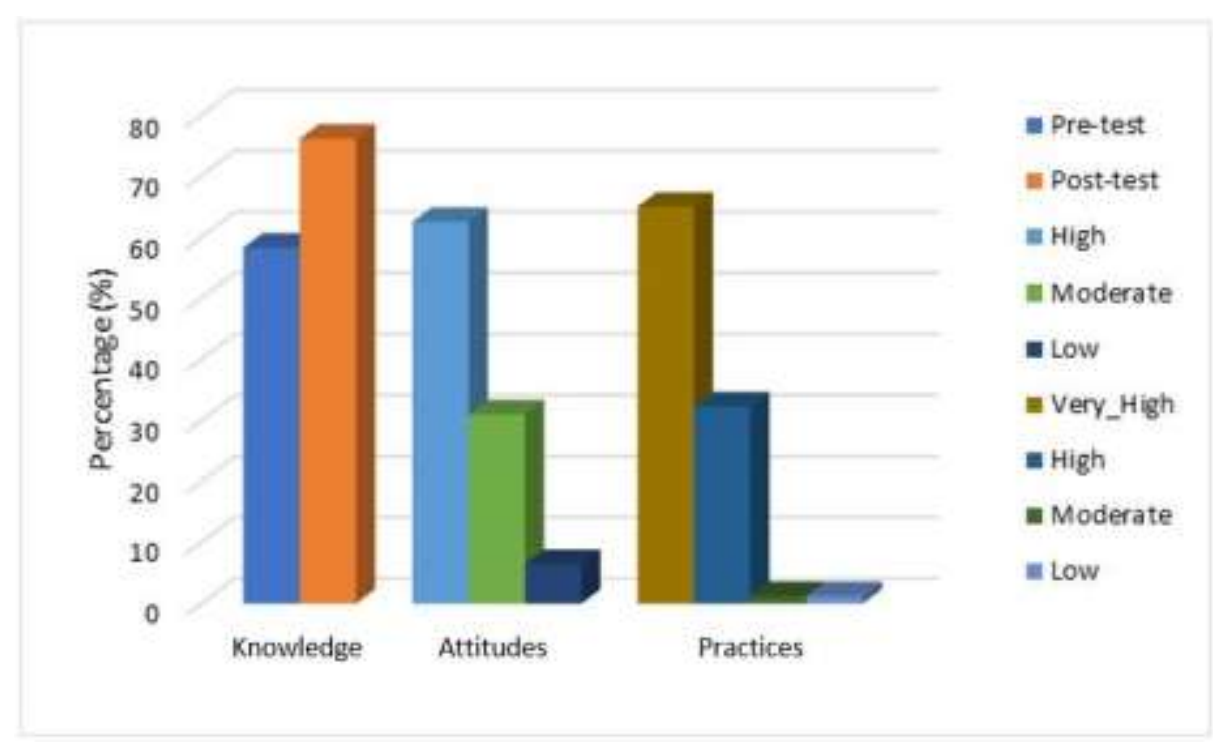

Figure 2. Bar diagram of knowledge, attitudes, and practices after socialization of COVID-19 $(n=40)$

Table 6. Correlation between community knowledge, attitudes, and practice by Spearman correlation coefficient test

\begin{tabular}{ll}
\hline Variable & $\mathrm{p}$ value \\
\hline Knowledge-Attitudes & 0.381 \\
Knowledge-Practices & 0.477 \\
Attitude-Practices & $0.001 *$ \\
\hline
\end{tabular}

* significant 
Table 7. Difference in participant's KAP by demographics by Crosstabulation (Chi square test)

\begin{tabular}{|c|c|c|c|c|c|c|c|c|c|}
\hline \multirow[t]{2}{*}{ Variable } & \multicolumn{3}{|c|}{ Knowledge } & \multicolumn{3}{|c|}{ Attitudes } & \multicolumn{3}{|c|}{ Practices } \\
\hline & $\begin{array}{l}\text { Poor } \\
\mathrm{n}(\%)\end{array}$ & $\begin{array}{l}\text { Good } \\
\mathrm{n}(\%)\end{array}$ & $\begin{array}{c}p \\
\text { value }\end{array}$ & $\begin{array}{l}\text { Poor } \\
\mathrm{n}(\%)\end{array}$ & $\begin{array}{c}\text { Good } \\
\mathrm{n}(\%)\end{array}$ & $p$ value & $\begin{array}{l}\text { Poor } \\
\mathrm{n}(\%)\end{array}$ & $\begin{array}{c}\text { Good } \\
\mathrm{n}(\%)\end{array}$ & $\begin{array}{c}p \\
\text { value }\end{array}$ \\
\hline \multicolumn{10}{|l|}{ Gender } \\
\hline Male & $2(15.4)$ & 11(84.6) & 0.286 & $6(46.2)$ & $7(53.8)$ & $0.042 *$ & $1(7.7)$ & $12(92.3)$ & 0.082 \\
\hline Female & $8(29.6)$ & 19(70.4) & & $4(12.8)$ & $23(85.2)$ & & $9(33.3)$ & 18(66.7) & \\
\hline \multicolumn{10}{|l|}{ Age } \\
\hline$<17$ & $0(0)$ & $0(0)$ & 0.488 & $0(0)$ & $0(0)$ & 0.553 & $0(0)$ & $0(0)$ & 0.370 \\
\hline $17-25$ & $5(33.3)$ & $10(66.7)$ & & $3(20)$ & $12(80)$ & & $2(13.3)$ & $13(86.7)$ & \\
\hline $25-30$ & $1(10)$ & $9(90)$ & & $4(40)$ & $6(60)$ & & $3(30)$ & $7(70)$ & \\
\hline $30-35$ & $0(0)$ & $2(100)$ & & $0(0)$ & $2(100)$ & & $0(0)$ & $2(100)$ & \\
\hline$>35$ & $10(25)$ & $30(75)$ & & $3(23.1)$ & $10(76.9)$ & & $5(38.5)$ & $8(61.5)$ & \\
\hline \multicolumn{10}{|l|}{ Education } \\
\hline Elementary School & $1(100)$ & $0(0)$ & 0.284 & $0(0)$ & $1(100)$ & 0.539 & $0(0)$ & $1(100)$ & 0.562 \\
\hline Junior High School & $1(25)$ & $3(75)$ & & $0(0)$ & $4(100)$ & & $0(0)$ & $4(100)$ & \\
\hline Senior High School & $5(19.2)$ & $21(80.8)$ & & $8(30.8)$ & $18(69.2)$ & & $7(26.9)$ & $19(73.1)$ & \\
\hline Diplome & $0(0)$ & $0(0)$ & & $0(0)$ & $0(0)$ & & $0(0)$ & $0(0)$ & \\
\hline Bachelor, Master and Doctoral & $3(33.3)$ & $6(66.7)$ & & $2(22.2)$ & $7(77.8))$ & & $3(33.3)$ & $6(66.7)$ & \\
\hline Degree & & & & & & & & & \\
\hline \multicolumn{10}{|l|}{ Marrital Status } \\
\hline Married & $4(21.1)$ & $15(78.9)$ & 0.532 & $3(15.8)$ & $16(84.2)$ & 0.374 & $6(31.6)$ & $13(68.4)$ & 0.374 \\
\hline Single & $6(31.6)$ & $13(68.4)$ & & $6(31.6)$ & $13(68.4)$ & & $3(15.8)$ & $16(84.2)$ & \\
\hline Divorced/Widowed/Widower & $0(0)$ & $2(100)$ & & $1(50)$ & $1(50)$ & & $1(50$ & $1(50)$ & \\
\hline
\end{tabular}

\section{DISCUSSION}

This study aimed to determine community knowledge, attitudes, and practices after COVID-19 socialization in two villages in East Java, Indonesia. There is minimal research published on this critical issue for Indonesian up to now. The study covered rural areas in East Java that needed to have socialization.

\section{Knowledge Before Socialization}

After being analysed, the pre-test part of this study's participants presented poor knowledge scores toward COVID-19 with having mean percentage only $58.33 \pm$ 30.97. Less than $50 \%$ participants who had good knowledge whereas the older subjects were more knowledgeable than the younger. Studies in Bangladesh, Malaysia, and Saudi Arabia demonstrated the similar findings to our study (Al-Hanawi et al 2020, Azlan et al 2020, Paul et al 2020). There might be some reasons behind the poor COVID-19 knowledge among participants (Paul et al 2020). They, rural people, might be unfamiliar about COVID-19 socialization and health protocol campaign through accurate sources (Muleme et al 2017). This indicated a significant education gap between centre and rural are in Indonesia, likely reflecting suboptimal public health information and dissemination regarding COVID-19, as similar revealed on other studies in Bangladesh (Ferdous et al 2020).

\section{Knowledge, Attitudes, Practices' After Socialization}

Socialization was a part of continuous strategy from government and its stakeholder to raise awareness of COVID-19 among all the citizen, included rural areas (Wardhana 2020). After getting socialization, the posttest part of this study's participants showed good knowledge scores toward COVID-19 with having mean percentage increased on $77.70 \pm 22.52$. Therefore, tailoring of the information provided by health officials and other media outlets on the disease needs to address the multifactorial nature of the drivers leading to increase knowledge (Ferdous et al 2020). Most participants have categorized as good attitudes towards COVID-19 in their villages, with mean of percentage 62.5 \pm 21.7 . The findings are in line with previous study in Bangladesh, Malaysia, and Saudia Arabia (AlHanawi et al 2020, Azlan et al 2020, Paul et al 2020). Furthermore, the mean of percentage of very high and high participants' practices were $65 \pm 13.8$ and $32.3 \pm 13.8$. The issue of preventive practices merits some comment since for some measures such as hand washing the results were remarkably similar to the findings other (Khan et al 2014, Nour et al 2015, Ferdous et al 2020, Srichan et al 2020).

Correlations Among Knowledge, Attitudes, and Practices

The practices of rural population regarding a particular issue depends on their understanding of the critical points and attitude toward it (Paul et al 2020). Interestingly, among the participants with poor knowledge scores, one-third had good practices scores 
before receiving socialization and getting increase after socialized. These results indicate the challenges of managing the pandemic on the part of the government both in policy making and implementing mitigation measures since even those with good knowledge may not practice accordingly $(\mathrm{p}=0.477)$. This is also reflected in participants' expectations of high fatality and contagion while showing poor awareness of the reasons for contagion (Paul et al 2020). Meanwhile, there is a robust correlation $(\mathrm{p}=0.001)$ between attitude and practices variable's after receiving COVID-19 socialization. This clearly indicates that policy makers must better educate the public through awareness campaigns as knowledge creates a more positive attitude to harness better practices and encourage constructive criticism.

\section{CONCLUSION}

Overall, the socialization of COVID-19 was useful to improve the community knowledge, attitudes, and practices in Rambipuji and Suci Village, Jember Districts, East Java, Indonesia. Before socialization, most of the people do not know about the difference between rapid and swab test, self-isolation, community support and some of myths and fact about COVID-19. After socialization, there was an improvement of community knowledge, positive attitudes and good behaviour which could prevent the transmission and inhibit the spread of the COVID-19 pandemic in Indonesia. Furthermore, continuous encouragement of COVID-19 socialization in wide areas of Indonesia was recommended.

\section{ACKNOWLEDGMENT}

We would like to thank Prof. Dr. Budi Santoso, dr., SpOG(K) (Dean of Faculty of Medicine, Universitas Airlangga, 2020-2025), Prof. Dr. Soetojo, dr., SpU(K) (Dean of Faculty of Medicine, Universitas Airlangga, 2015-2020), Ns. Sasmiyanto, S.Kep., M.Kes (Dean of Faculty of Health Science, University of Muhammadiyah Jember), Akhmad Suyuti (Headman of Suci Village, Jember Districts) and Dwi Dewi Setyorini (Headman of Rambipuji Village, Jember Districts) for their support to complete this research. This research has been funded by the Community Service Program of Universitas Airlangga under grant number 532/UN3/2020.

\section{REFERENCES}

Al-Hanawi MK, Angawi K, Alshareef N, et al (2020). Knowledge, attitude and practice toward covid-19 among the public in the Kingdom of Saudi Arabia: A cross-sectional study. Frontiers in Public Health 8, 110.

Aylward, Bruce (WHO); Liang, W. (PRC) (2020) Report of the WHO-China Joint Mission on Coronavirus Disease 2019 (COVID-19), The WHOChina Joint Mission on Coronavirus Disease 2019.

Azlan AA, Hamzah MR, Sern TJ, et al (2020). Public knowledge, attitudes and practices towards covid-19: A cross-sectional study in Malaysia. PLoS ONE 15, 115.

Cascella M, Rajnik M, Aleem A, et al (2020). Features, evaluation, and treatment of coronavirus (covid-19), United States of America, StatPearls Publishing.

Chu DK, Akl EA, Duda S, et al (2020). Physical distancing, face masks, and eye protection to prevent person-to-person transmission of SARS-CoV-2 and COVID-19: A systematic review and meta-analysis. The Lancet 395, 1973-1987.

Ferdous MZ, Islam S, Sikder T, et al (2020). Knowledge, attitude, and practice regarding COVID19 outbreak in Bangladesh: An onlinebased crosssectional study. PLoS ONE 15, 1-17.

Heaton PM (2020). The covid-19 vaccine-development multiverse. New England Journal of Medicine 383, 12.

Khan MU, Shah S, Ahmad A, et al (2014). Knowledge and attitude of healthcare workers about middle east respiratory syndrome in multispecialty hospitals of Qassim, Saudi Arabia. BMC Public Health 14, 1-7.

Muleme J, Kankya C, Ssempebwa JC, et al (2017). A framework for integrating qualitative and quantitative data in knowledge, attitude, and practice studies: A case study of pesticide usage in Eastern Uganda. Frontiers in Public Health 5, 1-15.

Nour MO, Bharti R, Alsaleem SA, et al (2015). Knowledge, attitude and practices of healthcare providers towards MERS-CoV infection at Makkah hospitals, KSA. Int Res J Med Med Sci 3, 103-112.

Paul A, Sikdar D, Hossain MM, et al (2020). Knowledge, attitudes, and practices toward the novel coronavirus among Bangladeshis: Implications for mitigation measures. PLoS ONE 15, 1-18.

Rodríguez-Morales AJ, MacGregor K, Kanagarajah S, et al (2020). Going global - Travel and the 2019 novel coronavirus. Travel Medicine and Infectious Disease 33, 1-6.

Srichan P, Apidechkul T, Tamornpark R, et al (2020). Knowledge, attitude and preparedness to respond to the 2019 novel coronavirus (COVID-19) among the bordered population of northern Thailand in the early 
period of the outbreak: A cross-sectional study. SouthEast Asia Journal of Public Health 9, 118-125.

Wang L, Wang Y, Ye D, et al (2020). A review of the 2019 Novel Coronavirus (COVID-19) based on current evidence. International Journal of Antimicrobial Agents 55, 1-8.

Wardhana Y (2020). Socialization of policy alternative models in efforts of handle covid-19 pandemic problems in Yosorejo village, Metro City. PICS-J: Pasundan International Community Services Journal 2, 91-97.

Wei-jie G, Ni Zy, Hu Y, et al (2020). Clinical characteristics of coronavirus disease 2019 in China.
The New England Journal of Medicine 382, 17081720.

World Health Organization (2020). WHO directorgeneral's opening remarks at the media briefing on covid-19 in 11 March 2020.

Pasaribu US, Mukhaiyar U, Huda NM, et al (2021). Modelling COVID-19 growth cases of provinces in java Island by modified spatial weight matrix GSTAR through railroad passenger's mobility. Heliyon 7, $\mathrm{e} 06025$. 